This article is available open access under a CC BY 4.0 license as part of Berghahn Open Anthro, a subscribe-to-open model for APC-free open access made possible by the journal's subscribers.

\title{
MONUMENTAL SUSPENSION
}

\author{
Art, Infrastructure, and Eduardo Chillida's Unbuilt \\ Monument to Tolerance
}

Isaac Marrero-Guillamón

\begin{abstract}
More than 25 years after it was unveiled, Eduardo Chillida's Monument to Tolerance has been neither built nor abandoned-it is, rather, suspended. From the outset, the project, which consists in digging a vast cubic cave inside the mountain of Tindaya (Fuerteventura, Canary Islands), has faced the opposition of environmental activists, who argue that it is incompatible with the mountain's status as a protected site. Drawing from anthropological approaches to infrastructure and art, this article unpacks the Monument's actual existence as an unrealized project that has been partly actualized through anticipatory practices such as exhibitions and economic aspirations. The article contributes to the theorization of suspension by combining a focus on the temporal multiplicity of anticipation with an attention to the materiality of unbuilt entities.
\end{abstract}

Keywords: anticipation, Canary Islands, Chillida, infrastructure, public art, social aesthetics, suspension, uncertainty

On 17 December 1996, a small exhibition entitled Monumental Project Tindaya Mountain opened at the Casa de la Cultura in Puerto del Rosario, Fuerteventura (Canary Islands). A selection of sculptures, architectural models, and drawings unveiled Eduardo Chillida's Monument to Tolerance-a huge cube to be excavated in the mountain of Tindaya, featuring two 'chimneys' that would let in the sunlight and moonlight and an entry tunnel that doubled as a viewing platform. The extraction of 200,000 cubic meters of rock would result in an astonishing sensorial concatenation: the possibility of standing on the exposed interior of the mountain, lit by the distant sun or moon, with a view over the 
island's dry plain culminating in the sea. The president of the government of the Canary Islands and the chancellor of tourism, guests of honor, expressed their conviction that the Monument was a "unique opportunity" for the island and the archipelago.

Meanwhile, a small protest was taking place outside. Activists held banners ("Chillida's Project= Tindaya's Destruction"; "Chillida's hole is filling the Government's pockets") and told anybody who would listen about the danger facing the sacred mountain of Tindaya. They also encouraged people to visit an alternative exhibition they had organized close by, at the Popular University building. Humbler in scope and means, the exhibition used a series of posters to introduce Tindaya's cultural and natural value. They explained that the mountain was a protected site by virtue of its exceptional indigenous remains, which included hundreds of foot-shaped engravings interpreted as a mark of the mountain's sacredness for the Maho people who inhabited the island before European colonization in the early 1400s. In addition, the mountain's rare geological attributes as a trachyte laccolith and the presence of an endangered plant, the cuernúa (Caralluma burchardii), had also received legal protection. Regardless of its artistic merit, the activists argued, it was clear that Chillida's project was incompatible with the mountain's protected status as a Natural Monument and Asset of Cultural Interest. The posters also denounced that despite the mountain's listed condition, there were three active quarries in Tindaya. The rock extracted there could be seen decorating the façades of a number of buildings such as Fuerteventura's airport and courthouse, the latter a few blocks away from the exhibition. The construction of the Monument, activists said, was a gross excuse to continue profiting from the mountain's trachyte.

From the outset, Chillida's proposed Monument was faced with the complications derived from Tindaya's multiple existence as an archaeological site, a protected environment, and a mining resource. ${ }^{1}$ In fact, the project was originally presented as an 'artistic solution' to this conundrum: the work would be built by redirecting the already existing rock extraction (hence honoring the companies' mining rights), while the archaeological remains, which were on the mountain's surface, would be untouched by the inner cube, the shafts, or the tunnel (hence respecting its sacredness). Others thought differently, however. As soon as Chillida's project was made public, concerned archaeologists and environmental activists started campaigning against it. They formed the Tindaya Mountain Coordinating Committee (Coordinadora Montaña Tindaya) and reclaimed the mountain's immediate and complete protection.

Twenty-five years later, the Monument has not been built-but neither has it been abandoned. It is, rather, suspended. State institutions still consider it a worthy possibility, and activists continue to protest against it regularly. After being shelved for years, the opening exhibition mentioned above has been on 
display since 2015 in a small museum in the village of Tindaya; the counterexhibition posters, meanwhile, can be found decorating the walls of Bar Maria, also in the village. During fieldwork conducted in 2016-2017, I would find the Monument dispersed in myriad documents, alluded to in several events, contested or praised in different spaces. An opportunity for some, a threat for others, Chillida's Monument to Tolerance definitely existed, albeit not in the form intended by the artist.

This article analyzes the Monument's suspension and its multiple effects. Drawing from Akhil Gupta's (2015) work, I understand suspension not as "a temporary phase between the start of a project and its (successful) conclusion," but as a mode of existence in its own right. This allows me to extricate the analysis from the teleology of completion/failure-what Carse and Kneas (2019) call 'project time'-and focus instead on the specific temporality and materiality of suspension. I argue that in the case of Chillida's Monument, suspension has produced two interrelated processes. First, it has redistributed the proposed artwork into multiple instantiations other than its construction, such as exhibitions, technical documents, and public presentations. Second, its indefinite postponement means that the Monument partakes in multiple temporalities at once. For some, it represents the promise of a brighter future yet to come or a former future that could have been, while for those who oppose it, it is experienced as a threat in the present. Below, I unpack the Monument's multiplicity across these two dimensions-material and temporal. Whereas the project's official narrative presents it as a work of autonomous art, my analysis reveals its many entanglements with economic and political matters. Drawing from science and technology studies (see Latour 1993; Mol 2002), I use the notions of entanglement and assemblage to challenge the modernist purification of Chillida's Monument and highlight instead how it is constituted by a range of heterogeneous, 'impure' relations.

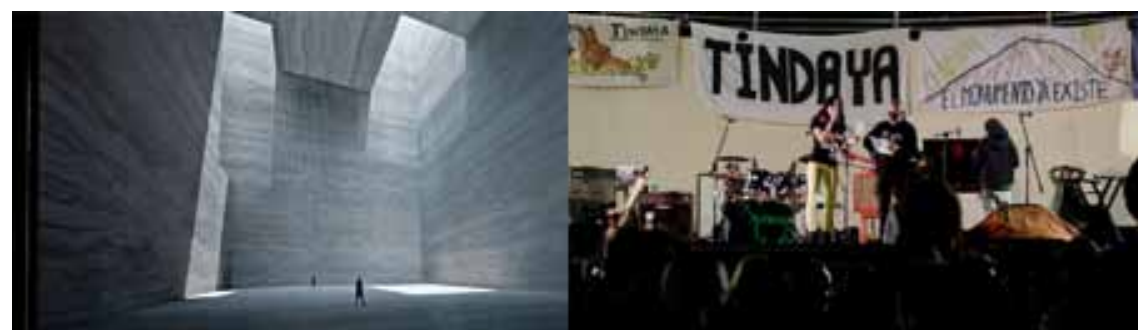

FigurE 1: The Monument as promise (official computer simulation, left), and as threat (activist event in defense of Tindaya, right). Both images taken from the film Tindaya Variations (Marrero-Guillamón 2018). 


\section{Art, Infrastructure, and Suspension}

The argument I develop in this article draws from two subfields that are currently only partially connected: the anthropology of infrastructure and the anthropology of art. Whereas Brian Larkin $(2013,2018)$ has articulated the need to incorporate questions of aesthetics in the study of infrastructure, I want to introduce an infrastructural perspective in the study of (certain) artworks. Large public art projects such as Chillida's Monument involve precisely the kind of assemblages of expertise, promise, and spectacle that the anthropology of infrastructure has so productively unpacked (see Appel et al. 2018). Furthermore, these are projects in which the aesthetic concerns of their creators are inevitably entangled with the political aspirations of the public bodies that fund them and the concerns of those who oppose them. To be clear, I am not advocating for reducing large public artworks to mere infrastructures-a gesture that would risk ignoring the specificity of art as a domain of practice with its own distinct history, institutional arrangements, aesthetic procedures, and so on. Rather, I argue that the socio-material orientation of the anthropology of infrastructure can be productively incorporated into the task of thinking with artistic projects of a certain scale, whose planning and construction-or indeed suspension-involve processes that greatly exceed the confines of the artworks, the artists, and their studios. More specifically, I draw from recent analyses of 'unbuilt and unfinished' (Carse and Kneas 2019) infrastructures in order to unpack the Monument's suspended existence and contribute to the theorization of suspension "as its own condition of being" (Gupta 2015).

For obvious reasons, temporality has been a central concern in the conceptualization of infrastructural deferrals and interruptions. As Ashley Carse and David Kneas (2019: 11) argue, this emerging body of literature "prompts us to think pluralistically about infrastructure and time. It draws our attention to how multiple temporalities can coalesce as planners, builders, politicians, potential users, and opponents negotiate with a project and each another." Elana Rowe (2017), for instance, discusses the enduring consequences of 'shelved futures' in relation to an unrealized gas extraction project in the Russian Artic. She concludes that the anticipatory practices and representations of the future attached to it have had "lasting repercussions for how economic development and environmental risks are understood in the region" (ibid.: 13), including disillusionment, skepticism, nostalgia, and also empowerment. These findings are echoed in Kirchherr et al.'s (2018) study of an unbuilt dam in Thailand that looms large in the life of the villages waiting to be displaced. Land speculation, investment deferrals, extreme anxiety, and enhanced solidarity were some of the effects of the uncertainty and anticipation associated with the dam's suspension. Gisa Weszkalnys's (2015) analysis of protracted oil exploration in São Tomé and Príncipe sheds light on how developmental 'pauses' are connected to 
a range of practices (or 'gestures') that speculate with, anticipate, and sustain the promise of petroleum futures-managing, in the process, to defer failure. These studies show how suspension is far from static. Rather than simply stopping time, the temporality of suspension is multiple and subjunctive-it involves, at once, "what was, what might be, and what may have been" (Carse and Kneas 2019: 12). Similarly, my analysis shows how the uncertainty regarding the future of Chillida's Monument is neither unitary nor paralyzing: it is, at once, a former future that some remember nostalgically, an opportunity that some anticipate eagerly, and a possibility that some fear may become true.

Suspension, therefore, does not refer to an absence of action; on the contrary, it describes a specific type of performativity connected to uncertainty-to a future that is both unknown and unknowable. I have alluded above to the temporal manifestations of suspension, but there is also a material footprint to be considered. Suspended projects often exist disseminated across media (e.g., brochures, computer-generated images) and in the form of anticipatory artifacts such as models. These objects are certainly charged with the promise and aspirations associated with the project and are capable of having powerful effects, not least counter-reactions. In the case of Chillida's Monument, the social life of the models and images tasked with making it public has been marked by discord. For instance, activists disrupted a royal visit to a version of the exhibition mentioned in the opening vignette when it was showing at Madrid's International Contemporary Art Fair (ARCO). Meanwhile, the official imagery of the Monument has been subjected to repeated détournement, and activist collectives have created their own visual counter-repertoire. Clearly, the agency of the (suspended) Monument is distributed across multiple objects and locales.

I am, in making this argument, invoking Alfred Gell's (1998: 16) theorization of artworks as "persons" or "social agents," that is, as performative entities, capable of exercising social agency in the form of new relations and “causal sequences” of events. Crucially, Gell's work was pragmatically directed toward analyzing what artworks $d o$, rather than what they may mean or represent. His theory of art was indeed devoted to the study of "social relations in the vicinity of objects mediating social agency” (ibid.: 7). In arguing so, Gell developed a relational anthropology of art modeled after anthropology at large, that is, a theory concerned with "the study of relationships over the life course" (ibid.: 11) of a given agent.

Gell's theory contributed to a turn to materiality and performativity in the anthropological study of art and visual culture, characterized by "shifts from meaning alone to mattering and from content to social process" (Edwards 2012: 228; see also Chua and Elliott 2013). I develop a similarly relational and pragmatist approach in this article, one that, following Georgina Born's (2010a, 2010b) and Antoine Hennion's ([1993] 2015) work on music, combines the analysis of the multiple entanglements that cultural artifacts are made of (and those 
produced by them) with an attention to their aesthetic qualities and experience. Unlike Gell, whose hasty exclusion of aesthetics from the anthropological analysis of art was predicated on a limited definition of aesthetics as judgments of taste and beauty, my goal-paraphrasing Hennion (2016: 292) -is to pursue an anthropology of art that is not to be carried out against it, but with it. Born et al.'s (2017) notion of 'social aesthetics' is particularly relevant in this regard. They use it to signal an analytics that refuses to "disentangle the social, in all its varied modalities, from experiences and conceptions of the aesthetic" (ibid.: 2). The result is a plural, non-universalist approach to aesthetic practices and objects. They elaborate their perspective as follows: "Art objects and events are thought to transcend their narrow material, temporal, and spatial boundaries and to participate vitally, richly, and vigorously in the larger socio-material assemblages within which they are created, circulated, and consumed-within which they and the subjects of aesthetic experience that they elicit and encounter together live their lives" (ibid.).

Challenging the separation between aesthetics and the social-'socializing aesthetics', we might say-is a central analytic strategy throughout this article. Contrary to the Monument's official presentation, which actively extricates it from the controversy and assumes its artistic autonomy, I focus on how Chillida's suspended Monument is multiply enacted, imagined, and challenged and how its artistic pretensions are entangled with political aspirations and activist concerns.

\section{The Making of the Suspended Monument}

In 1993, the regional and the island's governments commissioned a Special Protection Plan (SPP) for Tindaya with the explicit remit of providing a solution to the mountain's problematic multiplicity. As mentioned above, Tindaya features hundreds of indigenous engravings, by virtue of which it had been declared an Asset of Cultural Interest. ${ }^{2}$ In addition, the mountain's flora and singular geology had been recognized by the 1987 Natural Spaces Act, which listed it as a "site of regional interest," and during the preparation of the SPP the mountain was declared a Natural Monument under the new 1994 Natural Spaces of the Canaries Act. And yet, in spite of this legal protection, three quarries were operating in Tindaya at the time. The mountain's trachyte had been extracted for ornamental purposes, intermittently and in small quantities, at least since the late eighteenth century. But in 1982, 1983, and as late as 1993, the state granted new mining concessions to two companies, Cabo Verde and Cantería Arucas. Their operation was never full-time, since extraction took place in batches according to demand, and local labor was deployed only occasionally. Still, their imprint on the mountain was unmissable. The SPP was 
born out of the acknowledgment of the need to put an end to this conundrum: a mountain simultaneously protected and exploited within the law.

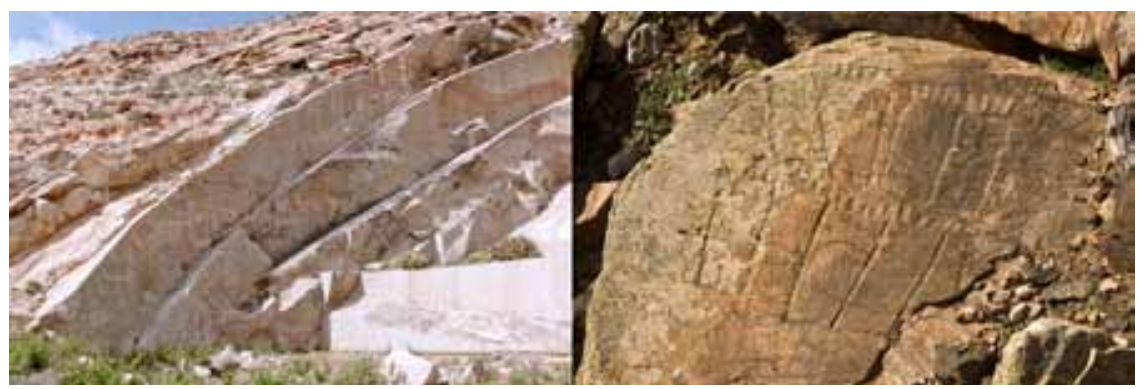

FiguRE 2: Tindaya's quarries and engravings. Left image by the author; right image courtesy of Juan Santana.

The team working on the SPP was led by architect José Miguel FernándezAceytuno. They developed an 'integrated strategy' for preserving, restoring, and promoting the area's cultural and natural heritage. Their plan rested on the immediate cessation of the quarrying, for which they proposed the compulsory purchase of the mining rights from the two companies that held them. The authorities rejected the strategy as economically inviable and invited the team to find an alternative solution. It was then that they discussed the possibility of an artistic intervention in the quarries through which the amount of rock needed to finance the purchase of the mining rights could be extracted. Interestingly, only art was thought to be able to provide a legitimate pretext for the team's paradoxical strategy: using rock extraction to put an end to rock extraction. The idea of ' $a$ Chillida' (at that point a metonym for an artist of international prestige) ${ }^{3}$ emerged during those conversations.

By sheer coincidence, José Antonio Fernández Ordóñez, a well-known engineer and long-time Chillida collaborator, was working in the Canary Islands at the time and heard about Tindaya in the course of a casual conversation with his colleague Fernández-Aceytuno. Shortly after, on the occasion of being inducted into San Fernando's prestigious Royal Academy of the Arts in March 1994, Chillida mentioned his intention of visiting a mountain in Fuerteventura in relation to an old idea of his: "sculpting a mountain and emptying it out by inserting space into it" (Olave 1994). ${ }^{4}$ Chillida explained how he had, for a number of years, been searching for a mountain where mining took place with the intention of directing the rock extraction in such a way that the resulting interior space had sculptural qualities. He had visited potential mountains accompanied by Fernández Ordóñez, but had not found them suitable. He had almost given up when this new possibility arose. 
However baffled by this unexpected circumstance, the SPP team and the vice-councillor of culture of the regional government, Miguel Cabrera, all agreed that the opportunity should be seized. Chillida received an official invitation (delivered in person), and shortly after, on 5 May 1994, at the age of 70, he arrived in Fuerteventura for the first time in his life, accompanied by his wife Pilar Benzunce and his trusted engineer Fernández Ordóñez. They stayed for four days, during which they visited Tindaya and had several meetings with the authorities and the SPP team. I spoke to two team members who were present at those meetings, and they remembered vividly how it soon became apparent that Chillida was not interested in a restorative intervention in the existing quarries, but rather in the "heart of the mountain," as he put it. Although he listened respectfully to their explanation of the archaeological importance of Tindaya and their approach to the conservation plan, they were left with the impression that Chillida was ultimately interested in something else-realizing his long-planned monumental intervention.

We may say that the Monument was born there and then, out of the peculiar encounter between an artist in search of a mountain and a team of architects in search of an artist. It can also be argued that the foundations for the Monument's future suspension were laid out during that visit as well, for it was then that the SPP's ingenious strategy for terminating the rock extraction, devised in the abstract, became something else altogether as soon as the artist and his renown came into the picture. Crucially, the government officials with a say over the SPP were instantly seduced by the prospect of Chillida (no longer a metonym) being involved, and his monumental project triggered a complete rescaling of the plans for Tindaya. The question was no longer one of resolving the mountain's tricky legal situation, but rather of generating a 'turning point' (un antes y un después) for the island and the archipelago. In fact, the governments of Fuerteventura and the Canary Islands enthusiastically supported Eduardo Chillida's intervention in Tindaya even before its specifications were available and despite the very significant legal, economic, and technical uncertainties surrounding it. Over the course of 1995, Chillida and Fernández Ordóñez produced some preliminary sketches of the Monument, which were sufficient for the government to commit to it and declare it "of regional interest." This legal designation had a very important effect: an ad hoc managing committee was created (formed by members of the departments of finance, industry, tourism, environment, heritage, and culture), and access to public funds was unlocked. In contrast, the SPP disappeared into bureaucratic oblivion soon after, effectively removing Fernández-Aceytuno and his team from the equation and extricating the planning and management of the Monument from considerations about its environment.

In theory, the managing committee should have been able to fast-track the project, but their involvement resulted in the exact opposite. The committee 


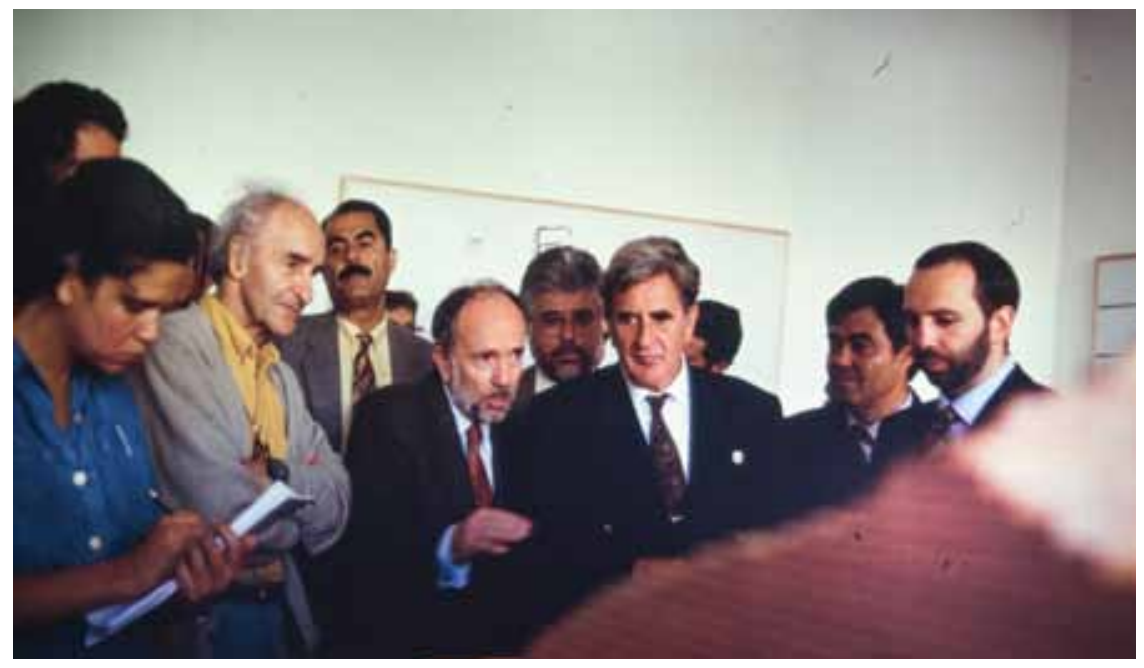

FiguRE 3: Official presentation of the Monument, 1996. At the center, the president of the Canary Islands government, Manuel Hermoso, listens to Fernández Ordóñez’s explanation. Image courtesy of Sofía Menéndez.

discarded the compulsory purchase of the mining rights-deemed inadequate, given that the situation called for a "fast and consensual solution" that allowed work on the project to start "as soon as possible"-and instead reached an agreement with Canterías Arucas and Cabo Verde. The former would receive roughly 900,000 euros, while the latter, whose rights were valued at approximately 5.4 million euros, would become a partner in the project. Cabo Verde was responsible for developing and executing Chillida's Monument through PMMT, ${ }^{5}$ a newly incorporated company that the government agreed to buy up in installments over a period of four years. This unusual procedure did not go unnoticed; it was immediately denounced by the opposition and taken to court by activists. The case became the first in a long series of corruption trials involving the purchase of the mining rights, personal connections between Cabo Verde and the regional government, and PMMT's own management. ${ }^{6}$ Later, activists took the government to court on two further accounts: the delimitation of Tindaya's archeological site, which limited the protection to the mountaintop, thereby allowing the construction of the Monument, and the decision to declare Chillida's Monument compatible with the conservation of the mountain's natural environment.

These multiple legal cases have grown to a monumental scale of their own and remain active as of 2020, certainly playing a key role in the Monument's suspension. The deaths of Chillida and Fernández Ordóñez in the early 2000s and the economic crisis that started at the end of that same decade have also 
contributed to its recurring postponement. As argued above, however, suspension is not simply the lack of completion, but rather a specific mode of existence. The government, which has never abandoned the idea of building the Monument, has continued investing in it through various technical studies and dissemination activities, spending a grand total of 25.7 million euros so far. Meanwhile, the activists' tireless campaigning against the Monument has produced its own forms of counter-presence including public talks, screenings, information stands, and leaflets designed to make public Tindaya's indigenous heritage and natural environment (see Marrero-Guillamón, forthcoming). As a result, the Monument exists today as both a promise and a threat, as a gateway to progress and an insult to indigenous heritage and sustainability.

\section{Infrastructuring Modernity}

It is clear that what is at stake in the Tindaya controversy is not only the future of the Monument and the mountain, but also opposing visions of progress, development, and heritage. Understanding these requires situating the controversy within the political economy and the cultural politics of the Canary Islands and Spain.

Before the European conquest, the archipelago was populated by groups of Amazigh origin who migrated from Northwest Africa around the year 100 in circumstances that remain unclear (Fregel et al. 2019). After a long period of intermittent contact with Europeans, the islands were colonized and incorporated into the Crown of Castile during the fifteenth century. Subsequent enslavement, deportation, and forced assimilation, among other forms of colonial violence, resulted in the annihilation of aboriginal societies (Adhikari 2017). This means that there is no contemporary indigenous population in the archipelago. Reading the Tindaya controversy as an(other) instance of indigenous land under attack by the state would therefore obscure the importance of the socio-cultural rupture produced by colonization.

Since the arrival of the Spanish, Fuerteventura became a periphery within the periphery. As a dry island exposed to devastating droughts and scarcely populated, it was not suited for the plantation economy and was favored as a military outpost instead. Until 1950, its population remained stable-between 10,000 and 13,000 inhabitants, largely dependent on small-scale agriculture. It was not until the 1970s that the island's radical metamorphosis into a prime destination for Spanish and European tourism began. During Franco's dictatorship (1939-1975), a program of economic 'aperture' started the process, which accelerated drastically with the first democratic governments ${ }^{7}$ and after Spain's entry into the European Economic Community in 1986 (López and Rodríguez 2011). A very rough approximation of the speed of Fuerteventura's 
transformation during that first developmental wave is provided by the following figures. In 1970, 8,500 tourist arrivals were registered in Fuerteventura; a decade later, the number was over 135,000, and in 1995, more than 912,000 (Bianchi 2004). In the same period, the island's population increased from just over 18,000 in 1970 to 30,000 in 1981 and almost 43,000 in 1996 (González Morales 2004).

Nationwide, the new influx of European capital and people brought with it an unprecedented program of investment in large infrastructure projects. ${ }^{8}$ It was a period characterized by what artist David Bestué (2015: 134) calls the "monumentalization of infrastructure." This was a phase of technical and budgetary exuberance, in which the state's demand for works of lasting impact that would unequivocally signify the nation's newfound modernity was met by engineers and architects (e.g., Santiago Calatrava, Frank Gehry) who were more than ready to monumentalize public infrastructures. Bestué's ideas about the symbiosis between certain political aspirations and sculptural languages can be understood in relation to Larkin's (2018: 175-176) argument that apart from "material assemblages caught up in political formations whose power in society derives from their technical functions ... [infrastructures] also operate aesthetically, and their aesthetic address constitutes a form of political action that is linked to, but differs from, their material operations." In this sense, between the mid-1980s and the 2008 crisis, the relationship between art and infrastructure in Spain had two distinct facets. On the one hand, art institutions became an infrastructure in and of themselves, as manifested in the extraordinary proliferation of museums, art centers, and auditoriums. ${ }^{9}$ On the other hand, the aesthetics of (modern) art was often adopted in the design of infrastructures, such as bridges designed like sculptures. In both instances, a clear rupture with the old, backward Spain of the dictatorship was staged. Sometimes clear and minimalist, more often flashy and overconfident, the public works of the time became politico-sensory statements, flagships of Spain's new democratic, modern condition.

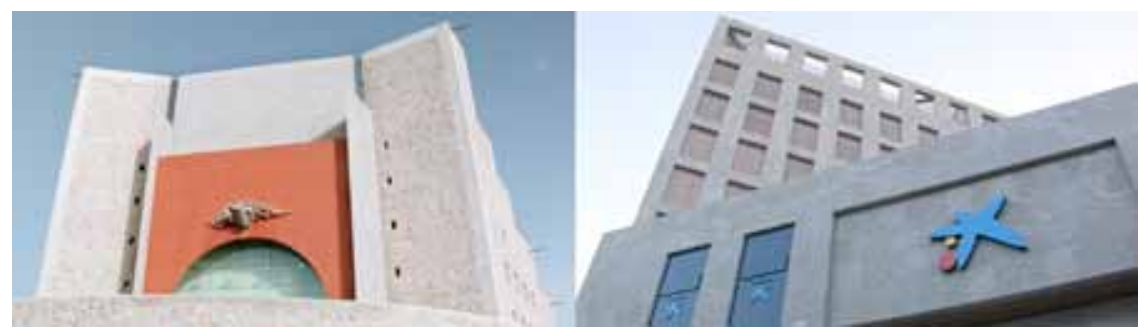

FigurE 4: Gran Canaria's auditorium and CajaCanaria's (now CaixaBank's) headquarters in Tenerife, two of the most iconic buildings featuring Tindaya's trachyte. Both images taken from the film Tindaya Variations (Marrero-Guillamón 2018). 
The Monument to Tolerance represented an opportunity to partake in the developmental paroxysm of the time: the Chillida-Fernández Ordóñez combination was simply irresistible for the outermost region's politicians. Miguel Cabrera, the person ultimately responsible for inviting Chillida, spoke publicly of a "once in a lifetime" opportunity: "[The Monument] would be a work of paramount importance for the island and the rest of the Canaries, so we are heavily committed to it in the Regional Government. Fuerteventura could become more than a 'sun and beach' tourist destination-a cultural destination of the highest magnitude” (Cabrera, quoted in García 1994). Twenty-three years later, a high official put it to me in very similar terms: "We are an island that feeds from tourism. Our industry is tourism, and tourism requires a lot of promotion. Fuerteventura, with Tindaya and Chillida, would raise the bar-it'd become a worldwide reference in culture the day after the Monument opened." 10

I find these images of instant and universal recognition rather telling of the expediency of public art for state officials. In their eyes, the Monument represents not just an attraction capable of attracting more (and better) tourists, but the very achievement of the modern break with the past. As numerous studies have made clear (see Harvey and Knox 2012), this is precisely one of the key functions of infrastructure: to act as symbols of progress, development, and modernity.

\section{Socializing Aesthetics}

One of the defining characteristics of the Monument to Tolerance is that despite its obvious role as a policy instrument, it was not only explicitly but adamantly conceived and presented to the public as a work of art. This is a claim that matters-one whose effects make a difference. In this section, I focus on how the idea of the autonomy of art was instrumental in extricating the suspended Monument from the controversy that surrounded it and contrast this official account with the insights derived from 'social aesthetics' - an approach that unpicks "the social and political conditions bearing on aesthetic experiences, objects, and practices" and directs our "attention to the social relations and social dynamics immanent in [artistic] works and practices as aesthetic events" (Born et al. 2017: 9).

Since 2015, the main interface between the suspended Monument and its intended public is the Casa Alta Museum in the village of Tindaya. Sited in a restored manor house, the museum hosts an expanded version of the 1996 exhibition previously described. The first room displays a new three-channel video that combines CGI simulations of the Monument with drone footage of the mountain. Both the images and the orchestral music that accompanies them are designed to amplify the epic scale of the project. One of the main CGI 
sequences, for instance, 'flies you' into the chamber through one of the vertical shafts. Once inside, the effect of the sunlight and the moonlight at different times of the year are simulated, while diminutive human bodies contemplate in awe the resulting transformation of the cave. The major tones and climatic crescendo of the music are audible in the second room, where one finds a wooden model of the mountain showing the imprint of the Monument's entry tunnel and two shafts; a glass cabinet with two metal cubes showing the relative sizes of the monument and the mountain; six stands with rock fragments from Tindaya, each featuring foot-shaped engravings; and two posters explaining, respectively, the mountain's environmental and cultural singularity. The third and last room, upstairs, features another wooden model of the mountain and its surroundings, a large selection of early drawings of the Monument, and a 1997 promotional film by Gonzalo Suárez entitled Chillida/Tindaya: A Process of Creation.

The exhibition's main argument is made explicit in its spatial arrangement and the texts that punctuate it: the Monument is not only compatible with Tindaya's archaeological and natural features, but it "sets the standard for how to act in nature" and "seeks to respect the same phenomena that our ancestors worshipped: the vital relation between the depths of the earth and the sun, the sea, and the moon." Put differently, the Monument is seen to correct the damage done by the quarries by redirecting the rock extraction, while also updating its sacredness by means of a grand contemporary intervention.

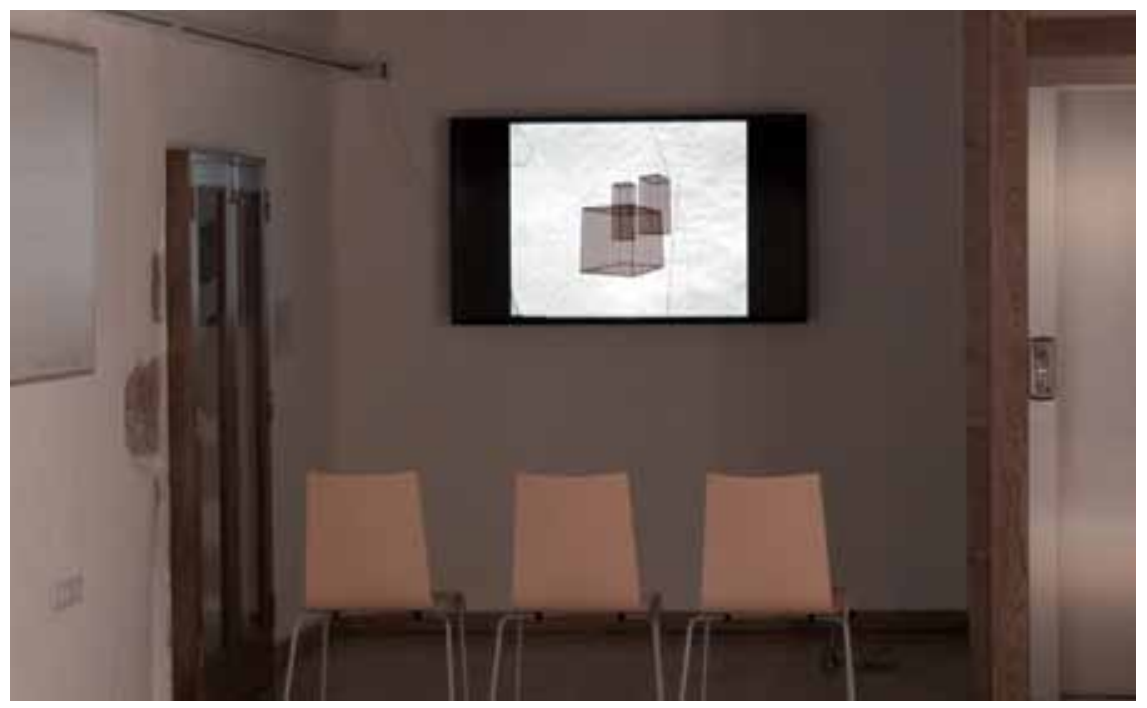

Figure 5: Casa Alta Museum exhibition, installation view. Image taken from the film Tindaya Variations (Marrero-Guillamón 2018). 
This thesis is delivered through the evacuation of conflict, technical matters, and even time from the exhibition. Starting with the last, most of the material on display treats Chillida's Monument as an imminent reality. The rehanging of the 1996 exhibition results in a remarkable temporal slippage: all of the text (on the walls as well as in the video's narration) is written in the present tense. It describes a Monument that "culminates" Chillida's work, that "puts an end" to the quarries, that "respects" Tindaya's sacredness, that "promotes" a new kind of tourism for the island. As a spectator, this celebratory grammar can be confusing, if not uncanny: there is no allusion whatsoever to the legal cases that have suspended the project for over 20 years, to Chillida's and Fernández Ordónez's deaths, or to the changes to the project during this time. In fact, unless one already knows, it is not clear whether the Monument has been built or not. However unintended, it is precisely this combination of asynchronous design and optimism that generates an aesthetics of suspension-a form of presentation that brackets off time and allows both Chillida's transcendental understanding of the Monument and the state's projection of formidable futures onto it to remain unchecked. Hence, the preference for the disembodied abstraction of CGI and the clean lines of architectural sketches. The key politico-aesthetic operation in this regard is the framing of the project as a timeless, autonomous work of art, extricated from any trace of antagonism or technical complexity.

Chillida certainly played a role in attempting to dissociate the Monument from a controversy he conceived as a completely separate issue. Not surprisingly for an artist of his generation and modernist inclination, Chillida's (1996) understanding of his own work was firmly inscribed in a formalist traditionart as a self-contained practice, devoted to the exploration of matter and form, decidedly unconcerned by politics or economics (see also Martínez 2001). This is a view shared by Kosme de Barañano (1997: 187), the exhibition's original curator, for whom the main conceptual frame of reference for the Monument can be found in Chillida's lifelong exploration of the possibilities of "creating a place by removing matter and introducing space." He argues that the essential subtractive gesture that defines the Monument can be found in a number of previous works, ${ }^{11}$ the key idea being that the project for Tindaya is analogous to these, only at a grand scale.

For a number of reasons, such formalist reductionism is untenable from a social aesthetics perspective. I have already discussed how contemporary art and architecture were enlisted by the state in the pursuit of modern 'progress' in post-Francoist Spain. The Monument was publicly funded with the expectation that it would make a difference in the island's economy and image; its scale and financing set it apart from Chillida's sculptures. Furthermore, as José Díaz Cuyás (2003) has pointed out, there is another fundamental difference between creating a sculptural object and intervening in a landscape. The latter 
encompasses not only the physical characteristics of a given site, but also its social, cultural, geological, political, and historical dimensions, all of which are ignored or instrumentalized in Chillida's project-for instance, by claiming that the Monument 'updates' the mountain's sacredness.

The official presentation of the Monument centers the artist's agency at the expense of the multiple other actors involved. The effacement of the mountain's affordances is exemplary in this regard. Chillida envisioned the Monument as a self-sustained inner cube, similar to those he himself had sculpted. The mining engineers tasked with making the project viable, however, concluded that in order to avoid the collapse of the cavity and/or the mountain, an invisible support structure needed to be built. ${ }^{12}$ Visitors would continue to experience the cubic penetration Chillida had envisioned, but the ceiling would be sustained by an array of cables hanging from a concealed service chamber. The geology of the mountain-more specifically, the basalt dykes that transverse it-meant that Chillida's elegantly conceived cube could not be built without a hidden scaffolding structure. Díaz Cuyás (2003) contends that this is more than a simple technical 'solution'; it is also a significant conceptual displacement. It does matter that the work cannot be built as originally intended. It does make a difference that the mountain's geology cannot withstand the cave without extra support. The result is nothing short of a travesty. As Díaz Cuyás concludes: "The technical procedures behind the artistic gesture are masqueraded, and it is intended that the modern demiurge can create a pure space inside the mountain in the same way that he would in a rock" (ibid.: 160).

None of these transformations, however, are mentioned at the Casa Alta Museum. The only images on display show the Monument that Chillida imagined, rather than the one that would actually be built. Similarly, there is no
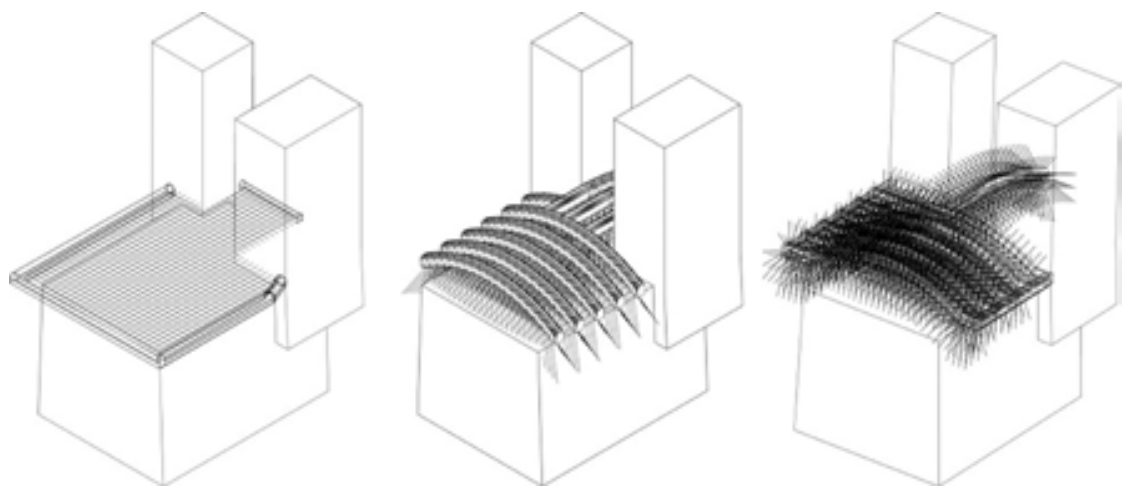

FIGURE 6: Three approaches to the support structure for the ceiling tested during the preparation of the 2007 technical specifications. The one on the right was chosen. Images courtesy of Arup. 
trace of conflict in the exhibition. The Monument is lifted from and elevated above the material and social constraints that have shaped it.

Formally and conceptually, Chillida's project relates to an artistic lineage of monumental works (often unbuilt or unfinished) that are designed to generate overwhelming experiences of landscape through subtractive gestures. The exhibition catalogue (Barañano 1997) proudly reclaims this tradition, citing examples such as Tony Smith's Mountain Piece (1968), Charles Ross's Star Axis (1971-present), and James Turrell's Roden Crater (1972-present). ${ }^{13}$ A recurring criticism of this kind of 'land art' relates to its arrogance and to its treatment of landscape as a mere terrain of human domination. Critics have connected this (in)sensibility with a colonial, frontier attitude reminiscent of the American West (Tufnell 2006) and have denounced "its remove from contemporary social and political concerns, its self-aggrandizing scale and temporality" (Swenson 2015: 62). I believe that these critiques are also relevant in the case of the Monument-a project that instrumentalizes the mountain's indigenous sacredness as a platform for its own transcendental aspirations, and whose management and dissemination, far from aspiring to contribute in some way to it, consistently shy away from a democratic public sphere. ${ }^{14}$

\section{Conclusion}

Suspension, I have argued, is a mode of existence in and of itself (see Gupta 2015, 2018). It describes a condition of unresolvedness that cannot be fully grasped through a focus on what it is not (a state of completion, failure, or abandonment), but requires instead delving into the effects it generates, that is, what it does. Put differently, suspension does not describe an absence of action or a state of temporal paralysis, but rather a specific kind of performativity associated with uncertainty and contingency. A growing body of literature analyzing uncompleted infrastructures has shown how the uncertainties surrounding postponement or interruption translate into a range of anticipatory practices. In other words, unbuilt and unfinished projects already exist; they may be enacted as promises (Hetherington 2014), preceded by speculation (Weszkalnys 2015), or experienced as sources of anxiety (Kirchherr et al. 2018) and frustration (Rest 2019). As Weszkalnys (2014) has shown, to anticipate is not the same as to wait or to expect: it is an affective state that involves acting on the premonition that something may be about to happen (see Adams et al. 2009).

My analysis of Chillida's proposed Monument in Fuerteventura clearly resonates with these insights. Its indefinite suspension has acted as a platform for both the state's vision of a prosperous future and the activists' actions against what they perceive as an impending threat to indigenous heritage and the environment. I have also argued that the Monument cannot be reduced to a mere 
tourist infrastructure; the fact that it was conceived, justified, and presented as a work of art is an inescapable aspect of its social life. In this regard, I have shown how the focus on temporality typical of the anthropological literature on infrastructural interruptions needs in this case to be complemented with a dedicated attention to materiality and aesthetics. On the one hand, suspension redistributes an entity's presence; rather than a single actualization, it produces multiple partial instantiations such as models, plans, and visualizations. The materiality of suspension is therefore as far from static as its temporality; suspension is prolific. On the other hand, as a work of modernist art, the Monument partakes in a series of aesthetic claims that I have explored critically. Drawing from Born et al.'s (2017) concept of 'social aesthetics', I have challenged the idea of the autonomy of art that is central to the Monument's official presentation, and have discussed some of the manifest ways in which the social and the aesthetic are entangled in this particular project.

My larger theoretical point is that suspension is a performative state characterized by temporal multiplicity and material redistribution-one in which the uncertainty about the future translates into practices of anticipation and partial instantiations. A suspended entity is an entity that is not quite yet, that exists in the subjective, as a hypothetical, indeterminate possibility that "could have been ... and may or may not turn out to be" (Zeiderman 2016: 171). The unknown and unknowable future of the suspended entity does not mean, however, that it is not material, or that it cannot offer an aesthetic experience. As discussed above, the actually existing suspended Monument-the one that can be encountered in promotional exhibitions and publications-has generated its own distinct aesthetics: atemporal, optimistic, purified. The Monument's public presentation entirely brackets off the technical complexities and controversy that surround it, re-enacts the developmental enthusiasm of Spain in the 1990s, and instrumentalizes indigenous heritage by means of the language of transcendental art. The Monument is literally suspended-lifted from the social, political, economic, and geological tensions that otherwise hold it. In her discussion of the aesthetics of suspension in contemporary Black cinema, Lauren Cramer (2017: 144-145) explains that "there is actually nothing weightless or immaterial about suspension," that there is an important "difference between the visual effect of suspension (hovering and lightness) and the process that creates suspension (force and pressure)." Similarly, I approach the Monument's so-called autonomy, or purity, as a convenient image-one that masks its multiple, and rather impure, entanglements (see Latour 1993).

My focus on the Monument's multiple effects responds to a pragmatist orientation to the study of suspension, an approach concerned with the question of what difference the Monument's unresolvedness makes, to itself as well as to others. The analysis reveals a multiple and conflicting existence: an entity that is redistributed across media, that partakes in various temporalities, that is 
differently perceived as a grand artwork, a political promise, or a threat to the mountain of Tindaya. Hence, the Monument is much more than an unrealized project. It is a performative entity already enmeshed in the social, an artwork whose suspension places it in a state of radical contingency, a work of art that is at once 'not yet' and 'what could have been'.

\section{Acknowledgments}

A British Academy/Leverhulme Small Research Grant funded this research project, which is also part of TURICOM (MICINN PGC2018-093422-B-I00). This article has benefited from the insight and generosity of many friends and colleagues. Alice Elliot, Chris Moffat, Ana Paola Gutiérrez, Gabriel Dattatreyan, and Martin Wemyss read and commented on different drafts. Adolfo Estalella, Alberto Corsín, and Roger Sansi opened up generous spaces of discussion where I could explore some of these ideas. Brais Vilarinho contributed to the project in ways that far exceeded his contractual remit. Last but not least, I thank the reviewers and editors who pushed me to find and refine my argument.

Isaac Marrero-Guillamón is a Lecturer in Anthropology at Goldsmiths, University of London, where he convenes the MA in Visual Anthropology. His work explores the entanglements between politics and aesthetics, often in the context of conflicts and controversies. He has conducted ethnographic research in Spain and the United Kingdom. His publications include the co-edited volumes Reassembling Activism, Activating Assemblages (2019) and The Art of Dissent: Adventures in London’s Olympic State (2012). E-mail: i.marrero@gold.ac.uk

\section{Notes}

1. The enactment of Tindaya's multiplicity by way of legal, economic, and activist devices is the central concern of a 'companion' article (Marrero-Guillamón, forthcoming). The focus on the mountain itself-as opposed to the suspended Monument-reveals the specific processes through which 'nature' and 'value' have been articulated throughout the controversy.

2. Despite the designation, this extraordinary archaeological site had only been preliminarily researched and was not delimited or protected.

3. Best known as a sculptor, Eduardo Chillida (San Sebastián, 1924-2002) is one of Spain's most recognized artists of his generation. Major retrospectives of his work have been organized at the Guggenheim Museum (New York and 
Bilbao); the Carnegie Institute, Pittsburgh; the Hayward Gallery, London; and the Museo Reina Sofia, Madrid.

4. Translations are my own, unless otherwise indicated.

5. The acronym stands for Proyecto Monumental Montaña Tindaya (Tindaya Mountain Monumental Project).

6. See Mesa (2013) for a summary of the corruption trials and controversies surrounding the development of Chillida's Monument.

7. The first general elections held after Franco's death took place in 1977, and the Spanish Constitution, which establishes the modern administrative division of the country into Autonomous Regions, was approved in 1978.

8. These large infrastructure projects include, among others, a high-speed rail network (now the second largest in the world, after China's); new airport constructions and refurbishments (for a grand total of 48 airports, the most in Europe); new metro and light rail systems (e.g., those in Valencia, Barcelona, Sevilla, Bilbao, and Tenerife); and countless new highways, bridges, and tunnels.

9. There were 12 contemporary art museums in Spain in 1981, and 126 in 2014-a proportion not to be found in any other country (Marzo 2014). In the Canary Islands, new modern art museums opened in Las Palmas de Gran Canaria and Santa Cruz de Tenerife (the latter designed by Herzog and de Meuron), as well as new auditoriums by Oscar Tusquets and Santiago Calatrava.

10. Interview conducted on 10 February 2017.

11. The list of precursors would include the sculptures Homage to Kandinsky (1965), Empty Mountain (1983), How Profound Is the Air (1983-1996), and Homage to the Light XX (1990), as well as Chillida's intervention in the Zabalaga estate, which saw a traditional sixteenth-century farmhouse stripped of everything but the sustaining structure and external walls.

12. It took five years (2003-2007), 1,650 meters of test drillings, and 1.6 million euros for these studies to be completed by the design and engineering firm Arup.

13. Turrell's project is an obvious point of reference for the Monument. Sited in a volcanic cone in northern Arizona, the work consists in excavating a series of tunnels and apertures that open onto the sky and create "a gateway to the contemplation of light, time and landscape” (http://rodencrater.com/about/). It is designed to experience both the interior of the volcano and its relationship to celestial bodies - a void that doubles as an optical mechanism. It is also a colossal work (more than 45 years in the making) supported by epic language: "Roden Crater belongs to a tradition of monumental structures that have been built by artists, rulers and priests, ancient and modern” (http://rodencrater. com/celestial-events/).

14. This is possibly the main topic in public art since the late 1980s (Deutsche 1992). 


\section{References}

Adams, Vincanne, Michelle Murphy, and Adele E. Clarke. 2009. "Anticipation: Technoscience, Life, Affect, Temporality.” Subjectivity 28 (1): 246-265.

Adhikari, Mohamed. 2017. "Europe’s First Settler Colonial Incursion into Africa: The Genocide of Aboriginal Canary Islanders.” African Historical Review 49 (1): 1-26. Anand, Nikhil, Akhil Gupta, and Hannah Appel, eds. 2018. The Promise of Infrastructure. Durham, NC: Duke University Press.

Appel, Hannah, Nikhil Anand, and Akhil Gupta. 2018. "Introduction: Temporality, Politics, and the Promise of Infrastructure." In Anand et al. 2018, 1-38.

Barañano, Kosme de. 1997. “Integrating Art and Nature.” In Montaña Tindaya Eduardo Chillida, ed. Kosme de Barañano and Lorenzo Fernández Ordóñez, 29-86. Fuerteventura: Gobierno de Canarias.

Bestué, David. 2015. "Formas libres: La influencia de la escultura en la ingeniería española reciente" [Free forms: The influence of sculpture on recent engineering works in Spain]. El Estado Mental 7: 132-138.

Bianchi, Raoul V. 2004. "Tourism Restructuring and the Politics of Sustainability: A Critical View from the European Periphery (the Canary Islands)." Journal of Sustainable Tourism 12 (6): 495-529.

Born, Georgina. 2010a. "For a Relational Musicology: Music and Interdisciplinarity, Beyond the Practice Turn.” Journal of the Royal Musical Association 135 (2): 205-243.

Born, Georgina. 2010b. "The Social and the Aesthetic: For a Post-Bourdieuian Theory of Cultural Production.” Cultural Sociology 4 (2): 171-208. doi:10.1177/1749975510368471.

Born, Georgina, Eric Lewis, and Will Straw. 2017. "What Is Social Aesthetics?” In Improvisation and Social Aesthetics, ed. Georgina Born, Eric Lewis, and Will Straw, 1-30. Durham, NC: Duke University Press.

Carse, Ashley, and David Kneas. 2019. "Unbuilt and Unfinished: The Temporalities of Infrastructure." Environment and Society 10 (1): 9-28.

Chillida, Eduardo. 1996. “'Hace años tuve una intuición'” [“Years ago I had an intuition”]. El País, 27 July.

Chua, Liana, and Mark Elliott, eds. 2013. Distributed Objects: Meaning and Mattering after Alfred Gell. New York: Berghahn Books.

Cramer, Lauren M. 2017. "Icons of Catastrophe: Diagramming Blackness in Kahlil Joseph's Until the Quiet Comes.” liquid blackness 3 (7): 142-168.

Deutsche, Rosalyn. 1992. "Art and Public Space: Questions of Democracy.” Social Text 33: 34-53.

Díaz Cuyás, José. 2003. "Arte del suelo y espacio público: El paradigma de Tindaya” [Land art and public space: The Tindaya paradigm]. Basa 27: 136-161.

Edwards, Elizabeth. 2012. "Objects of Affect: Photography Beyond the Image." Annual Review of Anthropology 41: 221-234.

Fregel, Rosa, Alejandra C. Ordóñez, Jonathan Santana-Cabrera, et al. 2019. "Mitogenomes Illuminate the Origin and Migration Patterns of the Indigenous 
People of the Canary Islands.” PLOS ONE 14 (3). https://journals.plos.org/ plosone/article?id = 10.1371/journal.pone.0209125.

García, Catalina. 1994. “Chillida: 'Haré todo por realizar la obra en la montaña de Tindaya'” [Chillida: "I will do everything I can to build the project in Tindaya"]. Canarias7, 6 May.

Gell, Alfred. 1998. Art and Agency: An Anthropological Theory. Oxford: Clarendon Press.

González Morales, Alejandro. 2004. "La población de la isla de Fuerteventura 1857-2001” [Fuerteventura's population: 1857-2001]. Tebeto: Anuario del Archivo Histórico Insular de Fuerteventura 17: 337-456.

Gupta, Akhil. 2015. "Suspension.” Society for Cultural Anthropology, 24 September. https://culanth.org/fieldsights/suspension.

Gupta, Akhil. 2018. "The Future in Ruins: Thoughts on the Temporality of Infrastructure.” In Anand et al. 2018, 62-79.

Harvey, Penny, and Hannah Knox. 2012. "The Enchantments of Infrastructure.” Mobilities 7 (4): 521-536.

Hennion, Antoine. (1993) 2015. The Passion for Music: A Sociology of Mediation. Trans. Margaret Rigaud and Peter Collier. Farnham: Ashgate.

Hennion, Antoine. 2016. "From ANT to Pragmatism: A Journey with Bruno Latour at the CSI.” Trans. Stephen Muecke. New Literary History 47 (2-3): 289-308.

Hetherington, Kregg. 2014. "Waiting for the Surveyor: Development Promises and the Temporality of Infrastructure." Journal of Latin American and Caribbean Anthropology 19 (2): 195-211.

Kirchherr, Julian, Teerapong Pomun, and Matthew J. Walton. 2018. “Mapping the Social Impacts of 'Damocles Projects': The Case of Thailand's (as yet Unbuilt) Kaeng Suea Ten Dam.” Journal of International Development 30 (3): 474-492.

Larkin, Brian. 2013. "The Politics and Poetics of Infrastructure." Annual Review of Anthropology 42: 327-343.

Larkin, Brian. 2018. "Promising Forms: The Political Aesthetics of Infrastructure." In Anand et al. 2018, 175-202.

Latour, Bruno. 1993. We Have Never Been Modern. Trans. Catherine Porter. Cambridge, MA: Harvard University Press.

López, Isidro, and Emmanuel Rodríguez. 2011. “The Spanish Model.” New Left Review 69: 5-29.

Marrero-Guillamón, Isaac, dir. 2018. Tindaya Variations. Documentary film, 40 min. https://tindayavariations.net/.

Marrero-Guillamón, Isaac. Forthcoming. "More Than a Mountain: The Contentious Multiplicity of Tindaya (Fuerteventura, Canary Islands).” Journal of the Royal Anthropological Institute.

Martínez, Sanjuana. 2001. “Eduardo Chillida: 'El arte está ligado a lo que todavía no se crea"” [Eduardo Chillida: "Art is linked to that which is not yet created"]. Babab 9. http://www.babab.com/no09/eduardo_chillida.htm.

Marzo, Jorge Luis. 2014. "Las políticas de lo público en el arte” [The politics of the public in art]. Periférica Internacional: Revista para el análisis de la cultura $y$ el territorio (15): 59-70. 
Mesa, Macame. 2013. “Tindaya: La utopía truncada” [Tindaya: A truncated utopia]. El Diario, 31 October. http://www.eldiario.es/canariasahora/premium_ en_abierto/Tindaya-utopia-truncada_0_191781871.html.

Mol, Annemarie. 2002. The Body Multiple: Ontology in Medical Practice. Durham, NC: Duke University Press.

Olave, Carlos. 1994. "Sigo buscando una montaña para meter el espacio en su interior" [I continue to search for a mountain where space can be introduced]. $A B C$, 20 March.

Rest, Matthäus. 2019. “Dreaming of Pipes: Kathmandu’s Long-Delayed Melamchi Water Supply Project.” Environment and Planning C: Politics and Space 37 (7): 1198-1216.

Rowe, Elana W. 2017. "Promises, Promises: The Unbuilt Petroleum Environment in Murmansk." Arctic Review on Law and Politics 8: 1-14. https://arcticreview. no/index.php/arctic/article/view/504.

Swenson, Kirsten. 2015. "On Francis Alÿs, When Faith Moves Mountains (2002).” In Critical Landscapes: Art, Space, Politics, ed. Emily Eliza Scott and Kirsten Swenson, 60-62. Oakland: University of California Press.

Tufnell, Ben. 2006. Land Art. London: Tate Publishing.

Weszkalnys, Gisa. 2014. "Anticipating Oil: The Temporal Politics of a Disaster Yet to Come." Sociological Review 62 (S1): 211-235.

Weszkalnys, Gisa. 2015. “Geology, Potentiality, Speculation: On the Indeterminacy of First Oil.” Cultural Anthropology 30 (4): 611-639.

Zeiderman, Austin. 2016. Endangered City: The Politics of Security and Risk in Bogotá. Durham, NC: Duke University Press. 